\title{
Guidelines
}

\section{Guideline for the Acquisition and Preparation of Conventional and Endobronchial Ultrasound-Guided Transbronchial Needle Aspiration Specimens for the Diagnosis and Molecular Testing of Patients with Known or Suspected Lung Cancer}

\author{
Erik H.F.M. van der Heijden ${ }^{a}$ Roberto F. Casal ${ }^{b}$ Rocco Trisolinic ${ }^{c}$ Daniel P. Steinfort ${ }^{d}$ \\ Bin Hwangbo ${ }^{\text {e Takahiro Nakajima }}{ }^{f}$ Birgit Guldhammer-Skov ${ }^{g}$ Giulio Rossi ${ }^{\text {h }}$ \\ Maurizio Ferretti ${ }^{i}$ Felix F.J. Herth ${ }^{j}$ Rex Yung ${ }^{k}$ Mark Krasnik \\ on behalf of the World Association for Bronchology and Interventional Pulmonology \\ Task Force on Specimen Guidelines

\begin{abstract}
a Department of Pulmonary Diseases, Radboud University Medical Center, Nijmegen, The Netherlands; ${ }^{b}$ Department of Pulmonary and Critical Care Medicine, Baylor College of Medicine and Michael E. DeBakey VA Medical Center, Houston, Tex., USA; ' Thoracic Endoscopy and Pulmonology Unit, Ospedali Maggiore e Bellaria,

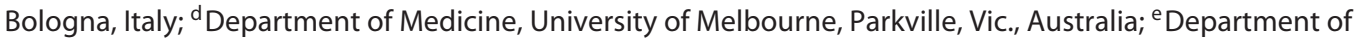
Pulmonology, National Cancer Center, Goyang, South Korea; ${ }^{\mathrm{f} D e p a r t m e n t}$ of General Thoracic Surgery, Graduate School of Medicine, Chiba University, Chiba, Japan; ${ }^{9}$ Department of Pathology, University Hospital Rigshospitalet, Copenhagen, Denmark; ' Department of Pathology, Azienda Policlinico, Modena, and 'Cytopathology Unit, Azienda Ospedaliero-Universitaria Ospedali Riuniti, Ancona, Italy; ${ }^{j}$ Department of Pneumology and Critical Care Medicine, Thoraxklinik and Translational Lung Research Center Heidelberg, Member of the German Lung Research Center, University of Heidelberg, Heidelberg, Germany; ${ }^{\mathrm{k}}$ Department of Pulmonary and Critical Care Medicine, Greater Baltimore Medical Center, Baltimore, Md., USA; 'Department of Cardiothoracic Surgery, University Hospital Rigshospitalet, Copenhagen, Denmark
\end{abstract}

\begin{abstract}
Rationale: Conventional transbronchial needle aspiration (TBNA) and endobronchial ultrasound (EBUS)-TBNA are widely accepted tools for the diagnosis and staging of lung cancer and the initial procedure of choice for staging. Obtaining adequate specimens is key to provide a specific histologic and molecular diagnosis of lung cancer. Objectives: To develop practice guidelines on the acquisition and preparation of conventional TBNA and EBUS-TBNA specimens for the diagnosis and molecular testing of (suspected) lung cancer. We hope to improve the global unification of procedure
\end{abstract}

standards, maximize the yield and identify areas for research. Methods: Systematic electronic database searches were conducted to identify relevant studies for inclusion in the guideline [PubMed and the Cochrane Library (including the Cochrane Database of Systematic Reviews)]. Main Results: The number of needle aspirations with both conventional TBNA and EBUS-TBNA was found to impact the diagnostic

Writing Panel: E.H.F.M.v.d.H. (chair), R.F.C., R.T., D.P.S., B.H., T.N. and M.K. (Cyto-)Pathology Expert Review Committee: B.G.-S. and G.R.

WABIP Expert Review Panel: R.Y., F.J.F.H. and M.F.

\section{KARGER}

E-Mail karger@karger.com www.karger.com/res (c) 2014 S. Karger AG, Basel

0025-7931/14/0886-0500\$39.50/0
Erik H.F.M. van der Heijden, MD, PhD

Department of Pulmonary Diseases (614), Radboud University Medical Center PO Box 9101, NL-6500 HB Nijmegen (The Netherlands)

E-Mail erik.vanderheijden@ radboudumc.nl 
yield, with at least 3 passes needed for optimal performance. Neither needle gauge nor the use of miniforceps, the use of suction or the type of sedation/anesthesia has been found to improve the diagnostic yield for lung cancer. The use of rapid on-site cytology examination does not increase the diagnostic yield. Molecular analysis (i.e. EGFR, KRAS and ALK) can be routinely performed on the majority of cytological samples obtained by EBUS-TBNA and conventional TBNA. There does not appear to be a superior method for specimen preparation (i.e. slide staining, cell blocks or core tissue). It is likely that optimal specimen preparation may vary between institutions depending on the expertise of pathology colleagues.

(c) 2014 S. Karger AG, Basel

\section{Introduction}

Clinical evidence-based guidelines are an important contribution to health care worldwide. Many national and international associations have published procedures or teaching guidelines to guide interventional pulmonologists, chest physicians and surgeons performing bronchoscopy or endobronchial ultrasound (EBUS). Nevertheless, there are currently considerable differences in the practice of these procedures worldwide. The World Association for Bronchology and Interventional Pulmonology (WABIP) Executive Board believes that its role in promoting the art and science of bronchology and interventional pulmonology warrants that the WABIP proposes a guideline to specifically address specimen handling of material obtained by conventional transbronchial needle aspiration (TBNA) and EBUS-guided TBNA.

Conventional TBNA has been used for many decades for the diagnosis and staging of lung cancer. In the last few years, EBUS-guided TBNA has been successfully introduced into our daily clinical practice. These techniques are of particular interest in patients with suspected lung cancer, centrally located tumors, sarcoidosis and other diseases accompanied by mediastinal or hilar lymphadenopathy and localized mediastinal diseases. Early EBUS studies have focused on assessing the accuracy and safety of the technique. The highly convincing results have led to incorporating this technique as a first step in the diagnosis and staging of patients with (suspected) lung cancer $[1,2]$. Surgical staging procedures such as cervical mediastinoscopy can thus be reserved for cases with highly suspicious mediastinal nodes (pathologic by either CT and/or PET scan) after a negative endosonographic staging and for restaging procedures after induction therapy.

EBUS and TBNA Specimen Handling Guideline
The recommendations for a cervical mediastinoscopy state that surgeons need to sample both contralateral and ipsilateral nodes plus the subcarinal region in every case, but adherence to these guidelines is low [3-5]. Given the importance of obtaining adequate tissue for diagnosis, accurate and complete staging with EBUS-guided TBNA, optimal specimen acquisition and preparation are key [6]. In addition, treatment planning including the use of targeted therapies and chemotherapy regimens critically depends on the availability of adequate specimen samples. With this document, we aim to present a practical evidence-based guideline to optimize procedure outcome in daily clinical practice, stimulate standardization of specimen handling techniques and provide a practical procedure description.

\section{Methods}

Systematic electronic database searches were conducted in order to identify potentially relevant studies for inclusion in the guideline. For each topic area, the following databases were searched: PubMed and the Cochrane Library (from 1992; including the Cochrane Database of Systematic Reviews). Searches were first run in September 2012. They were saved and run on a monthly basis to identify newly published literature to date and last updated in January 2014. Searches included a combination of index and free text terms, and were limited to English language publications only. The initial search identified 780 potential papers using the following search terms: 'lung neoplasms' [Mesh], lung cancer or nsclc, and tbna, transbronchial needle aspiration, ebus, endobronchial ultrasound, ebus, ebus-tbna, endosonography' [Mesh].

Within this set of papers, additional searches were performed to address specific questions. Furthermore, references from individual papers were scanned, and additional papers were manually added to search results.

Quality metric assessment and grading of the quality of evidence for clinical guidelines was performed systematically using WABIP check lists for case series and cross-sectional studies, the National Institute for Health and Clinical Excellence checklist, and the observational study methodology assessment and the clinical guideline grading system of the American College Chest Physicians.

The following four patient investigation/intervention comparator outcome (PICO) questions were formulated:

\section{PICO Questions 1-4}

(1) Among patients with known or suspected lung cancer, do conventional TBNA and EBUS-guided TBNA acquisition techniques [number of aspirates per target, needle type, use of miniforceps, use of suction, type of sedation, time spent inside the node and number of revolutions in the node (needle movements from the proximal to the distal side of the lymph node, LN)] affect the quantity and quality of the specimen for diagnosis? 
Table 1. Specimen acquisition techniques for conventional TBNA and EBUS-TBNA: summary of evidence, outcome parameters, and quality indicators: does the number of aspirates per LN/target lesion affect the diagnostic yield?

\begin{tabular}{|c|c|c|c|c|c|c|c|}
\hline $\begin{array}{l}\text { First } \\
\text { author }\end{array}$ & Study design & Population & $\begin{array}{l}\text { Inter- } \\
\text { vention }\end{array}$ & $\begin{array}{l}\text { Com- } \\
\text { parator }\end{array}$ & $\begin{array}{l}\text { Primary } \\
\text { objective } \\
\text { (endpoint) }\end{array}$ & Outcome & $\begin{array}{l}\text { Quality } \\
\text { metric } \\
\text { indicator }\end{array}$ \\
\hline $\begin{array}{l}\text { Diacon } \\
{[8]} \\
2007\end{array}$ & $\begin{array}{l}\text { Prospective, } \\
\text { experimental, } \\
\text { non-randomized } \\
\text { trial }\end{array}$ & $\begin{array}{l}\text { All patients under- } \\
\text { going blind TBNA } \\
245 \text { patients } \\
374 \text { targets } \\
\text { (including both } \\
\text { peritracheo- and } \\
\text { endobronchial) }\end{array}$ & cTBNA & $\begin{array}{l}\text { Asp. } \\
1-5\end{array}$ & $\begin{array}{l}\text { Determine the number } \\
\text { of Asp. needed for an } \\
\text { optimal diagnostic yield }\end{array}$ & $\begin{array}{l}75 \% \text { overall diagnosis with } \\
\text { blind TBNA: of the } \\
\text { diagnostic ones, the yield per } \\
\text { Asp. was: } \\
1 \text { Asp. }=64.5 \% \text {; } 2 \text { Asp. } 87.4 \% \text {; } \\
3 \text { Asp. } 95.5 \% \text {; } 4 \text { Asp. } 98.4 \% \text {; } \\
5 \text { Asp. } 99.4 \%\end{array}$ & Fair \\
\hline
\end{tabular}

Asp. $=$ Aspirations; $\mathrm{cTBNA}=$ conventional TBNA.

(2) Among patients with known or suspected lung cancer, do conventional TBNA and EBUS-guided TBNA specimen preparation techniques (cytology slides, core tissue and cell block) affect the quantity and quality of the specimen for diagnosis?

(3) Among patients with known or suspected lung cancer who undergo conventional TBNA or EBUS-guided TBNA, does rapid on-site cytology examination (ROSE) affect the quantity, quality and yield of the specimens for diagnosis?

(4) Among patients with known lung cancer, do conventional TBNA and EBUS-TBNA acquisition techniques (as described in PICO 1), specimen preparation techniques (as described in PICO 2) or ROSE (as described in PICO 3 ) affect the ability to perform molecular testing (i.e. EGFR/ALK but also other markers with predictive/prognostic information, such as KRAS, ERCC1, RRM1, TS, PIK3CA and MET, for example)?

\section{Results of PICO Question 1}

Among patients with known or suspected lung cancer, do conventional TBNA and EBUS-TBNA acquisition techniques [number of aspirates per $L N$, needle type, use of miniforceps, use of suction, type of sedation, time spent inside the node and number of revolutions inside the node (needle movements from the proximal to the distal side of the lymph node, LN)] affect the quantity and quality of the specimen for diagnosis?

Several aspects of the TBNA and EBUS-TBNA acquisition technique have been identified and studied. Hence, this question has been further divided into multiple subquestions as follows:

Does the number of aspirates per LN affect the diagnostic yield, quantity or quality of the obtained specimen?

Yes (table 1).

A prospective study by Lee et al. [7] of EBUS-TBNA for mediastinal staging of patients with non-small cell lung cancer (NSCLC) showed that $100 \%$ adequacy and 95\% sensitivity were achieved with 3 aspirations per LN and did not increase with a 4 th. In this study, EBUSTBNA was performed for mediastinal staging of lung cancer in potentially operable patients with LN with a short axis of 5-20 $\mathrm{mm}$ on CT.

Regarding conventional TBNA, two prospective observational studies $[8,9]$ showed a maximum diagnostic yield $>95 \%$ when 4 aspirations per target were performed. In the study by Diacon et al. [8], the overall diagnostic yield of conventional TBNA was 75\%. How- 
Table 2. Specimen acquisition techniques for conventional TBNA and EBUS-TBNA: summary of evidence, outcome parameters and quality indicators: does needle type or needle size affect the diagnostic yield?

\begin{tabular}{|c|c|c|c|c|c|c|c|}
\hline $\begin{array}{l}\text { First } \\
\text { author }\end{array}$ & Study design & Population & Intervention & Comparator & $\begin{array}{l}\text { Primary } \\
\text { objective } \\
\text { (endpoint) }\end{array}$ & Outcome & $\begin{array}{l}\text { Quality } \\
\text { metric } \\
\text { indicator }\end{array}$ \\
\hline $\begin{array}{l}\text { Saji } \\
{[13]} \\
2011\end{array}$ & $\begin{array}{l}\text { Prospective, } \\
\text { experimental, } \\
\text { non- } \\
\text { randomized } \\
\text { trial }\end{array}$ & $\begin{array}{l}\text { Enlarged } \\
\text { mediastinal } \\
\text { or hilar LN, PET+ } \\
\text { LN }\end{array}$ & $\begin{array}{l}\text { EBUS } \\
21 \mathrm{G} \\
(\mathrm{n}=24)\end{array}$ & $\begin{array}{l}\text { EBUS } \\
22 \mathrm{G} \\
(\mathrm{n}=32)\end{array}$ & Diagnostic yield & $\begin{array}{l}\text { Accuracy in cytology ( } 21 \text { vs. } \\
22 \mathrm{G}): 91.7 \text { vs. } 65.6 \%(\mathrm{p}=0.02) ; \\
\text { accuracy in histology } \\
(21 \text { vs. } 22 \mathrm{G}): 95.8 \text { vs. } 81.3 \% \\
(\mathrm{p}=0.11)\end{array}$ & Poor \\
\hline $\begin{array}{l}\text { Yarmus } \\
{[11]} \\
2013\end{array}$ & $\begin{array}{l}\text { Retrospective } \\
\text { study }\end{array}$ & $\begin{array}{l}\text { Enlarged } \\
\text { mediastinal } \\
\text { or hilar LN } \\
\text { (AQuIRE } \\
\text { Data Registry) }\end{array}$ & $\begin{array}{l}\text { EBUS } \\
21 \mathrm{G} \\
(\mathrm{n}=249)\end{array}$ & $\begin{array}{l}\text { EBUS } \\
22 \mathrm{G} \\
(\mathrm{n}=995)\end{array}$ & $\begin{array}{l}\text { Diagnostic yield } \\
\text { and sample } \\
\text { adequacy } \\
\text { (per LN analysis) }\end{array}$ & $\begin{array}{l}\text { No difference in either } \\
\text { adequacy or diagnostic yield } \\
\text { (both per patient and per LN } \\
\text { analysis) by multivariate } \\
\text { hierarchical logistic regression } \\
\text { models }\end{array}$ & Fair \\
\hline $\begin{array}{l}\text { Oki } \\
{[10]} \\
2011\end{array}$ & $\begin{array}{l}\text { Prospective, } \\
\text { experimental } \\
\text { RCT }\end{array}$ & $\begin{array}{l}\text { Enlarged } \\
\text { mediastinal } \\
\text { or hilar LN, } \\
\text { or paratracheal } \\
\text { tumors }(\mathrm{n}=60)\end{array}$ & $\begin{array}{l}\text { EBUS } \\
21 \mathrm{G} \\
(\mathrm{n}=30)\end{array}$ & $\begin{array}{l}\text { EBUS } \\
22 \mathrm{G} \\
(\mathrm{n}=30)\end{array}$ & $\begin{array}{l}\text { Adequacy and } \\
\text { diagnostic yield of } \\
\text { 'histologic' } \\
\text { specimens }\end{array}$ & $\begin{array}{l}\text { Diagnostic yield (histology/ } \\
\text { cytology combined: } \\
21 \text { vs. } 22 \mathrm{G}): 70 \text { vs. } 73 \% \text { ( } \mathrm{p}= \\
0.78) ; \\
\text { adequacy of histologic } \\
\text { specimen }(21 \text { vs. } 22 \mathrm{G}) \text { : } \\
72 \text { vs. } 78 \%(\mathrm{p}=0.4)\end{array}$ & Fair \\
\hline $\begin{array}{l}\text { Harrow } \\
{[15]} \\
2000\end{array}$ & $\begin{array}{l}\text { Prospective, } \\
\text { experimental, } \\
\text { non- } \\
\text { randomized } \\
\text { trial }\end{array}$ & $\begin{array}{l}360 \text { patients with } \\
\text { known/suspected } \\
\text { lung cancer } \\
\text { undergoing } \\
\text { mediastinal staging }\end{array}$ & $\begin{array}{l}\text { Conventional } \\
\text { TBNA with } \\
\text { cytology } \\
\text { needles } \\
(21 \text { or } 22 \mathrm{G})\end{array}$ & $\begin{array}{l}\text { Blind TBNA } \\
\text { histology } \\
\text { needles } \\
(19 \mathrm{G})\end{array}$ & $\begin{array}{l}\text { Sensitivity and } \\
\text { predictors of a } \\
\text { positive TBNA } \\
\text { aspirate in } \\
\text { mediastinal staging } \\
\text { of lung cancer }\end{array}$ & $\begin{array}{l}\text { Sensitivity ( } 19 \text { vs. } 21 / 22 \mathrm{G} \text { ): } \\
57 \text { vs. } 41 \%\end{array}$ & Poor \\
\hline
\end{tabular}

ever, since no surgical confirmation for negative results was obtained, sensitivity is unknown. The cumulative yield was $95 \%$ for 3 aspirations and $98 \%$ for 4 aspirations. They concluded that 3 transbronchial needle aspirates per site are appropriate when only tissue diagnosis is sought and when alternative sites or sampling mo- dalities are available. At least 4 or 5 aspirates should be carried out at LN stations critical for the staging of lung cancer.

The study by Chin et al. [9] showed an overall diagnostic yield of 57\% (patient based). When 3 and 4 aspirations were performed, the cumulative proportions of the yield 
were $86 \%(50 / 58)$ and $93 \%(54 / 58)$, respectively. All positive results were achieved with 7 or fewer aspirates. They concluded that there is a plateau in yield after 7 transbronchial needle aspirates, which may be sufficient to obtain an optimal yield in assessing patients with lung cancer and mediastinal adenopathies.

Does the needle size affect the diagnostic yield, quantity or quality of the specimen?

No (table 2).

The only prospective randomized controlled trial (RCT) that analyzed this topic [10] failed to find a significant difference between EBUS-TBNA performed with a 22- and 21-gauge needle. The diagnostic yield was $70 \%$ with the 21 -gauge needle and $73 \%$ with the 22 -gauge needle $(\mathrm{p}=0.78)$. They also failed to find a difference in the adequacy of histologic specimens [72 $(21 \mathrm{G})$ vs. $78 \%$ $(22 \mathrm{G}) ; \mathrm{p}=0.4]$. Of note, this was a small study and probably underpowered to detect a small but clinically significant difference.

Two retrospective studies $[11,12]$ had similar results, also failing to find a difference in the overall diagnostic yield between EBUS-TBNA using 22- and 21-gauge needles. The study by Yarmus et al. [11] analyzed data from the AQuIRE (American College of Chest Physicians Quality Improvement Registry, Evaluation and Education) Data Registry with multicenter contributions; 249 procedures were performed with 21-gauge needles, and 995 were performed with 22 -gauge needles. No differences in either sample adequacy (per LN analysis) or diagnostic yield (both per patient and per LN analysis) were found. A small, prospective, nonrandomized study comparing EBUS-TBNA with 21- and 22-gauge needles found a greater accuracy in cytology specimens obtained with the 21 -gauge needle ( 91.7 vs. $65.6 \% ; \mathrm{p}=0.02$ ) [13]. However, this was a small trial biased by the lack of randomization and with a substandard accuracy for samples obtained with the 22-gauge needles.

As for the influence of needle size on the diagnostic yield of conventional TBNA, the literature suggests that better success rates are obtained with the use of 19-gauge needles, as compared with 22 -gauge needles, but these results come from a limited number of observational trials subjected to significant bias, and most studies lack randomization [14-17].

Does the use offorceps affect the diagnostic yield, quantity or quality of the specimen in patients with known or suspected lung cancer?

No (table 3).
Unfortunately, the few available studies on the use of EBUS forceps for LN biopsy focus on patients with a low probability of lung cancer' [18-22]. This is likely based on the potential benefit of obtaining histology for patients with benign disease and lymphomas. Chrissian et al. [18] compared EBUS-TBNA and EBUS miniforceps biopsy (MFB, with a diameter of $1 \mathrm{~mm}$ ) performed in the same LN (in tandem) and found no difference in the overall diagnostic yield (EBUS-TBNA 81\% vs. EBUS-MFB 91\%; $\mathrm{p}=0.09$ ). They did report an increase in the overall yield with the combination of EBUS-TBNA and MFB versus EBUS-TBNA alone ( 97 vs. $81 \%$, respectively; $\mathrm{p}<0.001$ ), but only 25 out of 74 examined LN were malignant. They also reported an increase in the yield for malignancies with EBUS-MFB ( 96 vs. $68 \%$; $p=0.008$ ), though this difference seemed to arise particularly from 4 cases of lymphoma that were all diagnosed using EBUS-MFB but were missed by EBUS-TBNA ( 100 vs. $0 \%$ ). There were no differences in the yield for benign diseases ( $88 \%$ for both techniques). Darwiche et al. [20] performed a similar study with a newly developed LN forceps, which is shaped like a needle when in the closed position, to allow for better wall penetration. However, they failed to find an increase in the overall yield (EBUS-TBNA $71 \%$ vs. EBUS forceps $83 \%$; nonsignificant, NS) and also found no increase in the yield for malignancies (EBUS-TBNA 80\% vs. EBUS forceps 75\%; $p=N S$ ), but in this study no patients with lymphoma were included. Yet, they did report an increased yield for granuloma detection indicating sarcoidosis (EBUS-TBNA 61\% vs. EBUS forceps 89\%; p < $0.05)$, but this seemed to be secondary to their very low yield with EBUS-TBNA, which was substantially lower than in previous reports in the literature [23-25]. Herth et al. [21] also suggested that the use of a $1.15-\mathrm{mm}$ miniforceps increased the diagnostic yield in patients with sarcoidosis (from 36 to $88 \%$ ) or lymphoma (from 35 to $81 \%$ ) in a series of 75 patients not suspected of having lung cancer, and, in a noncontrolled case series, the use of a bevel-tip needle forceps was studied [22]. Finally, a recent retrospective study performed by Wang et al. [26] comparing conventional EBUS-TBNA to EBUS-MFB in a population with $59 \%$ malignant disease showed that diagnostic yield was equal in both groups (94 vs. 95\%, respectively). Furthermore, they found that EBUS-TBNA rendered enough material for a diagnosis in 453/476 cases, thus negating the need for the additional MFB biopsy [26]. In conclusion, the use of a miniforceps does not seem to influence the diagnostic yield in lung cancer but may be useful in patients with a suspected lymphoma or sarcoidosis. 
Table 3. Specimen acquisition techniques for conventional TBNA and EBUS-TBNA: summary of evidence, outcome parameters and quality indicators: does the use of miniforceps biopsy (MFB) affect the EBUS-TBNA diagnostic yield?

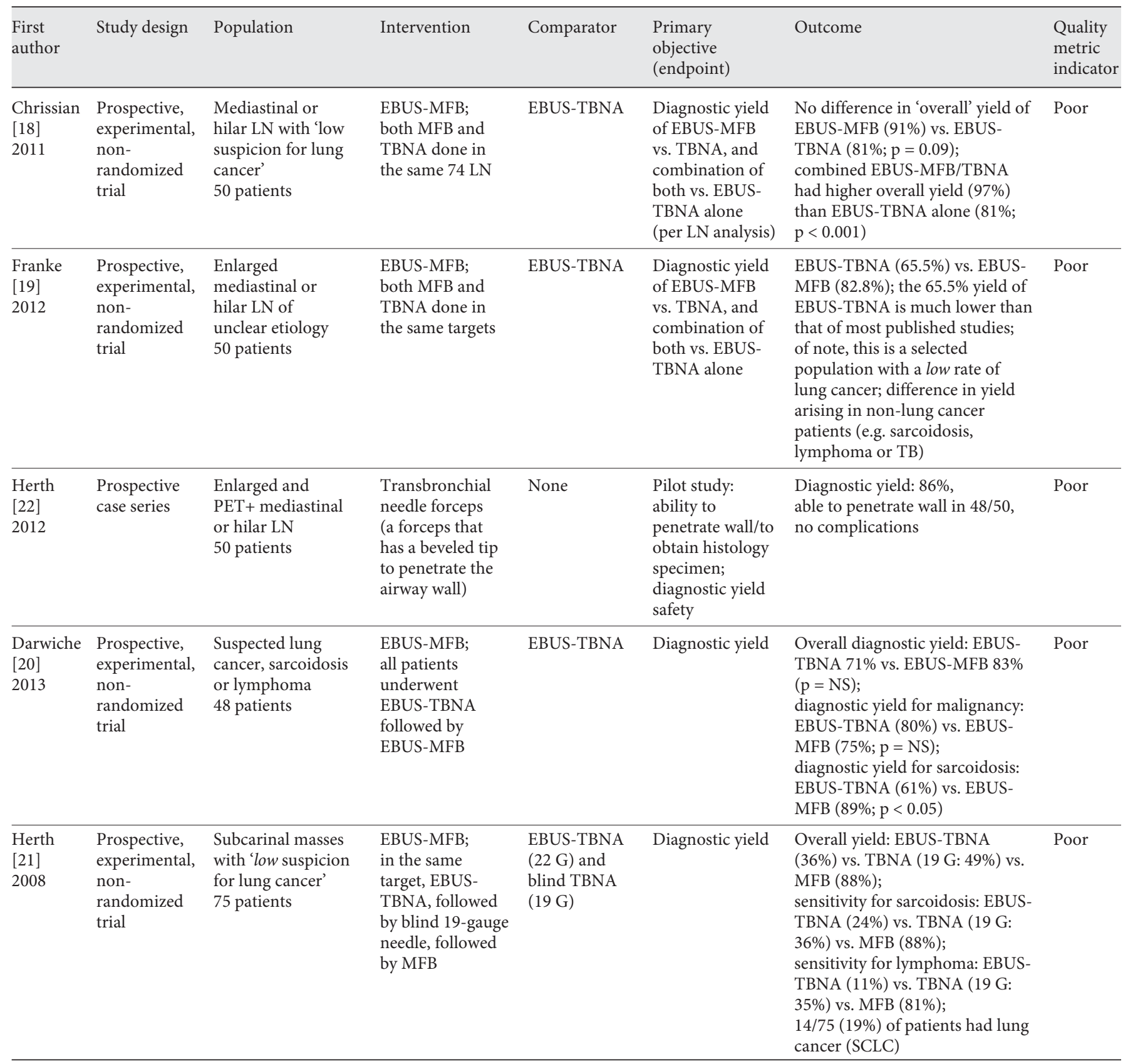

Does the use of suction affect the quantity and quality of the specimen, or the diagnostic yield?

No (table 4).

A prospective trial conducted by Casal et al. [27] compared EBUS-TBNA with EBUS biopsy without aspiration, referring to the latter as 'transbronchial needle capillary sampling' (TBNCS). Both techniques were employed in each LN, and the order in which they were performed was randomized to avoid the 'first-pass' effect. The authors reported no difference in sample adequacy, sample quality, diagnostic yield and specific diagnostic yield for malignancy [27]. A smaller prospec- 
Table 4. Specimen acquisition techniques for conventional TBNA and EBUS-TBNA: summary of evidence, outcome parameters and quality indicators: does the use of suction affect the quantity and quality of the specimen, or the diagnostic yield?

\begin{tabular}{|c|c|c|c|c|c|c|c|}
\hline $\begin{array}{l}\text { First } \\
\text { author }\end{array}$ & Study design & Population & Intervention & Comparator & $\begin{array}{l}\text { Primary } \\
\text { objective } \\
\text { (endpoint) }\end{array}$ & Outcome & $\begin{array}{l}\text { Quality } \\
\text { metric } \\
\text { indicator }\end{array}$ \\
\hline $\begin{array}{l}\text { Rodriguez } \\
{[29]} \\
2013\end{array}$ & $\begin{array}{l}\text { Prospective, } \\
\text { experimental } \\
\text { non- } \\
\text { randomized }\end{array}$ & $\begin{array}{l}\text { Patients with } \\
\text { mediastinal } \\
\text { LN or masses } \\
38 \text { patients }\end{array}$ & EBUS-TBNCS & None & & $\begin{array}{l}\text { Adequate sample: } 95.5 \% \text {; } \\
\text { specific diagnosis: } 84.1 \%\end{array}$ & Poor \\
\hline
\end{tabular}

tive study by Boonsarngsuk et al. [28] compared EBUS-TBNA with different levels of pressure: 0 (no suction), and -20 and $-40 \mathrm{~cm} \mathrm{H}_{2} \mathrm{O}$. In this study, only 1 biopsy was performed at each $\mathrm{LN}$ with a different pressure level $\left(0\right.$, and -20 and $\left.-40 \mathrm{~cm} \mathrm{H}_{2} \mathrm{O}\right)$. The diagnostic yield of EBUS-TBNA with -20 and $-40 \mathrm{~cm} \mathrm{H}_{2} \mathrm{O}$ was comparable (75.8 and $83.3 \%$, respectively), but higher than EBUS with no aspiration (63.6\%). However, this difference might arise from the low rate of adequate samples obtained by the authors when they employed no suction $(71 \%)$, which was much lower than that reported by Casal et al. [27] (88\%) and Rodriguez et al. [29] (95.5\%).

Does sedation/anesthesia type influence the quality of the specimen or the diagnostic yield?

No (table 5).

Data about the influence of the type of sedation/anesthesia on the yield of EBUS-TBNA are mostly based on retrospective studies and are largely inconsistent [30-32]. Adequate published data to address this question are lacking at the time these guidelines are established. A major concern is the lack of studies where com- plete mediastinal sampling is performed with sampling of an adequate number of $\mathrm{LN}$ regions (minimal $4 \mathrm{~L}, 4 \mathrm{R}$ and $7 \mathrm{LN} \geq 5 \mathrm{~mm}$ ). Hypothetically, the use of general anesthesia (GA) may facilitate performing a complete staging procedure meeting these minimal requirements stated in the guidelines of the European Society of Thoracic Surgeons [3]. The only prospective RCT on this topic is available as an abstract that has been accepted at the 18th World Congress for Bronchology and Interventional Pulmonology. This abstract reports preliminary interim results from a large prospective RCT performed by Casal et al. [27]. In their study, adults with an indication for EBUS-TBNA of mediastinal or hilar LN were randomized (1:1) to undergo the procedure under GA versus moderate sedation (MS). Cytologists were blinded to the randomization arm. The main objectives were diagnostic yield and sensitivity. A total of 57 procedures were performed under GA and 52 under MS by the time of the interim analysis. The median age of patients was 65 years (range 46-77) and 66 years (range 43-84) in the GA and MS groups, respectively. There were no significant differences in baseline comorbidities and American Society of Anesthesiologist scores. There were no differ- 
Table 5. Specimen acquisition techniques for conventional TBNA and EBUS-TBNA: summary of evidence, outcome parameters and quality indicators: does sedation/anesthesia type influence the diagnostic yield?

\begin{tabular}{|c|c|c|c|c|c|c|c|}
\hline $\begin{array}{l}\text { First } \\
\text { author }\end{array}$ & Study design & Population & Intervention & Comparator & $\begin{array}{l}\text { Primary } \\
\text { objective } \\
\text { (endpoint) }\end{array}$ & Outcome & $\begin{array}{l}\text { Quality } \\
\text { metric } \\
\text { indicator }\end{array}$ \\
\hline $\begin{array}{l}\text { Ost } \\
{[32]} \\
2011\end{array}$ & $\begin{array}{l}\text { Retrospective } \\
\text { study }\end{array}$ & $\begin{array}{l}\text { Enlarged mediastinal } \\
\text { or hilar LN } \\
\text { (AQuIRE Data } \\
\text { Registry) }\end{array}$ & $\begin{array}{l}\text { EBUS-MS } \\
\mathrm{n}=310\end{array}$ & $\begin{array}{l}\text { EBUS-GA } \\
\mathrm{n}=581\end{array}$ & $\begin{array}{l}\text { Determine risk- } \\
\text { adjusted diagnostic } \\
\text { yield }\end{array}$ & $\begin{array}{l}\text { Diagnostic yield: } \\
\text { MS }(46 \%) \text { vs. GA } \\
(52 \% ; \mathrm{p}=0.08) ; \mathrm{GA} \\
\text { is associated with } \\
\text { significantly more } \\
\text { and smaller LNs } \\
\text { sampled }(\mathrm{p}<0.001)\end{array}$ & Poor \\
\hline
\end{tabular}

ences in the indications for EBUS-TBNA: diagnosis (GA $32 \% / M S 31 \%$ ), staging (GA 26\%/MS 25\%), both diagnosis and staging (GA 33\%/MS 34\%) or restaging (GA 9\%/ MS 10\%). Per patient, an average of $3.03 \pm 1.8 \mathrm{LN}$ were sampled in the GA group versus $2.55 \pm 1.6$ in the MS group $(\mathrm{p}=\mathrm{NS})$. The average LN size was $11 \pm 6 \mathrm{~mm}$ (mean $\pm \mathrm{SD}$ ) in the GA group versus $12 \pm 7 \mathrm{~mm}$ in the MS group ( $p=N S)$. Procedure time (first scope in/last scope out) was $25 \pm 15 \mathrm{~min}$ in the GA group and $21 \pm$ 9 min in the MS group ( $\mathrm{p}=\mathrm{NS}$ ). In the MS group, the average dose of midazolam was $4 \mathrm{mg}$, and the average dose of fentanyl was $100 \mu \mathrm{g}$. Samples were adequate in $100 \%$ of $\mathrm{LN}$ in the GA group versus $99.8 \%$ of $\mathrm{LN}$ in the MS group. A specific diagnosis was found in $72 \%$ of patients in the GA group versus $67 \%$ in the MS group (p = NS). Sensitivity was $98 \%$ in the GA group and $94 \%$ in the MS group ( $p=N S$ ). Malignancy was found in $61 \%$ of GA group and $51 \%$ of MS group. There were no EBUSrelated complications in either group. Sedation-/anesthesia-related complications were only minor (transient hypoxemia, hypertension and tachyarrhythmia), and more common in the MS group (25 vs. $7 \%$; p < 0.05 ). After the procedure, patients' tolerance was assessed with a Likert scale questionnaire, and no significant difference was found. Based on these preliminary results from this RCT, the type of anesthesia seems to have no influence on the diagnostic yield of EBUS-TBNA, but a greater rate of minor sedation-related complications was detected in the MS group.

EBUS and TBNA Specimen Handling Guideline
Does the time spent inside the node or number of revolutions inside the node affect the diagnostic yield?

We have found no published studies on these aspects of the technique.

\section{Summary}

The effect of different aspects of the specimen acquisition technique with TBNA and EBUS-TBNA on the diagnostic yield was studied. There is enough evidence that 3 aspirations with EBUS-TBNA and 3-4 aspirations with conventional TBNA provide near the maximum yield, well above $90 \%$ of what is achievable by these techniques. Needle size ( 22 vs. $21 \mathrm{G}$ ) does not seem to influence the diagnostic yield according to a small prospective RCT and other retrospective reviews. Larger needles (18 and $19 \mathrm{G}$ ), which are typically utilized with conventional TBNA, are more likely to provide histologic cores. The use of forceps (miniforceps and needle forceps) was mainly described in a population with low risk of lung cancer. The results do not support its routine use in patients with known or suspected lung cancer. Most centers of expertise reserve this tool for cases where histology is strictly required (i.e. Hodgkin lymphoma). The diagnostic yield, sample adequacy and quality are similar when EBUS-TBNA biopsies are performed with negative pressure and without (TBNCS) aspiration.

We found no data investigating the effect of time spent inside the node or the number of revolutions inside the 
node, but, intuitively, a more prolonged sampling or higher number of needle revolutions may increase the risk of a bloody specimen.

Based on the preliminary results of a large RCT, the type of anesthesia does not seem to influence the diagnostic yield of EBUS-TBNA.

\section{Recommendations}

In patients with known or suspected lung cancer and enlarged mediastinal or hilar lymphadenopathies, or centrally located lung masses:

- At least 3 aspirates per nodal station are recommended with EBUS-TBNA for lung cancer staging when ROSE is not available and at least 3-4 aspirates for conventional TBNA.

Grade $1 B$

- There is not enough evidence to recommend any needle size over another for EBUS-TBNA, whereas evidence of limited quality suggests that 19-gauge needles used for conventional TBNA are more likely to provide histologic cores and possibly better success rates. Grade 2C

- There is not enough evidence to recommend the routine use of miniforceps or needle forceps for EBUS biopsies. Grade 2C

- There is not enough evidence to recommend for or against the use of suction with EBUS biopsies for diagnostic purposes. Grade $1 B$

- There is not enough evidence to recommend for or against any type of anesthesia. Grade $1 B$

\section{Results of PICO Question 2}

Among patients with known or suspected lung cancer, do conventional TBNA and EBUS-TBNA specimen preparation techniques (cytology slides, core tissue and cell block) affect the quantity and quality of the specimen for diagnosis?

Several aspects of TBNA and EBUS-TBNA specimen preparation techniques have been identified and studied. Hence, this question has been further divided into multiple subquestions as follows:

Do either cell block or tissue core techniques perform better in terms of diagnosis of lung cancer?

No (table 6).

We have not identified any trial directly comparing these two techniques and all identified studies were retrospective in nature. However, both techniques have been shown valuable for histologic diagnosis [33-42].

Numerous studies report the ability to prepare a cell block for morphologic and immunohistochemical (IHC) analysis. Yung et al. [33] have described the 'tis- sue coagulum clot cell block' (TCC-CB), where material collected by TBNA is expelled onto filter paper, allowed to congeal, then placed into formalin and processed as a histology specimen. In their study, they describe the rate of nondiagnostic specimens being significantly lower when the TCC-CB method was used (11\%) compared to when a cell block was prepared by saline rinse of the needle lumen (43\%) [33]. However, their observed rate of nondiagnostic specimens is markedly higher for cell block specimens compared with other reports where cell blocks have been formed by extruding material directly into formalin [39], liquid fixative $[38,43]$ or saline [40]. In these studies, diagnostic adequacy is equal to or exceeds that reported for the TCC-CB method.

Is there an optimal slide preparation technique and staining method?

No (table 7).

Very few studies have examined this question. One study [44] suggested that the less costly and labor-intensive method of Wright-Giemsa staining for ROSE provided equivalent diagnostic and quality performance compared to Papanicolaou staining. Another study [42] suggested that liquid-based cytology was resource saving in that only 1 slide required preparing and examination (compared to 7 for Papanicolaou staining), and that pathology reporting time may be reduced by up to $20 \mathrm{~min}$ per case. In studies identified by the literature search, multiple methods are used, including Papanicolaou, Wright-Giemsa and rapid Romanowsky staining, all of which appear to offer reasonable diagnostic performance. There is no quality evidence to suggest any particular method is preferable to others.

\section{Summary}

Multiple techniques for specimen acquisition and preparation have been reported in the literature though no direct comparisons of these techniques have been performed. Cytology slides are generally adequate for the diagnosis of malignancies and NSCLC subclassification, though the use of specimen preparation techniques that allow cell block formation in general improve the ability to determine NSCLC subclassification $[6,45,46]$. When needed, the smear used for ROSE can be destained and used for definitive cytological assessment (and immunocytochemistry or molecular pathology).

There does not appear to be a superior method for specimen preparation. It is likely that optimal specimen 
Table 6. Specimen preparation techniques for conventional TBNA and EBUS-TBNA: summary of evidence, outcome parameters and quality indicators: do either cell block or core tissue techniques perform better in terms of diagnosis of lung cancer?

\begin{tabular}{|c|c|c|c|c|c|c|c|}
\hline $\begin{array}{l}\text { First } \\
\text { author }\end{array}$ & Study design & Population & Intervention & Comparator & $\begin{array}{l}\text { Primary } \\
\text { objective } \\
\text { (endpoint) }\end{array}$ & Outcome & $\begin{array}{l}\text { Quality } \\
\text { metric } \\
\text { indicator }\end{array}$ \\
\hline $\begin{array}{l}\text { Sanz- } \\
\text { Santos } \\
{[34]} \\
2012\end{array}$ & $\begin{array}{l}\text { Retrospective, } \\
\text { observational } \\
\text { cohort study }\end{array}$ & $\begin{array}{l}\text { EBUS-TBNA of } \\
\text { mediastinum for } \\
\text { Dx/staging NSCLC }\end{array}$ & $\mathrm{CB}$ & $\begin{array}{l}\text { Pap. } \\
\text { smear }\end{array}$ & $\begin{array}{l}\text { Diagnosticl } \\
\text { adequate } \\
\text { specimen }\end{array}$ & $\begin{array}{l}\text { Where CB was available, Dx rate } \\
\text { was } 7.7 \% \text { higher than in patients in } \\
\text { whom only smears were available }\end{array}$ & Fair \\
\hline $\begin{array}{l}\text { Amin } \\
{[35]} \\
2013\end{array}$ & $\begin{array}{l}\text { Retrospective, } \\
\text { observational } \\
\text { cohort study }\end{array}$ & Not stated & $\begin{array}{l}\text { 'Blood clot } \\
\text { core' (similar } \\
\text { to TCC-CB) }\end{array}$ & $\begin{array}{l}\text { Pap. } \\
\text { smear }\end{array}$ & $\begin{array}{l}\text { Diagnostic } \\
\text { yield/ } \\
\text { specimen } \\
\text { adequacy }\end{array}$ & $\begin{array}{l}\text { Evaluation of blood clot core } \\
\text { achieved increase of } 7 \% \text { compared } \\
\text { to smear alone }(\mathrm{p}=\mathrm{NS})\end{array}$ & Fair \\
\hline $\begin{array}{l}\text { Tournoy } \\
{[37]} \\
2012\end{array}$ & $\begin{array}{l}\text { Retrospective, } \\
\text { observational } \\
\text { cohort study }\end{array}$ & $\begin{array}{l}\text { EBUS-diagnosed } \\
\text { NSCLC in patients } \\
\text { who had separate } \\
\text { biopsies to serve as } \\
\text { references }\end{array}$ & $\mathrm{CB}$ & No CB & $\begin{array}{l}\text { Accuracy } \\
\text { of cell } \\
\text { typing }\end{array}$ & $\begin{array}{l}\text { Use of CB improves ability to } \\
\text { subclassify NSCLC }\end{array}$ & Fair \\
\hline $\begin{array}{l}\text { Navani } \\
{[38]} \\
2012\end{array}$ & $\begin{array}{l}\text { Multicenter } \\
\text { retrospective, } \\
\text { observational } \\
\text { cohort study }\end{array}$ & $\begin{array}{l}\text { Patients with } \\
\text { suspected } \\
\text { NSCLC }\end{array}$ & $\mathrm{HE}$ & IHC & $\begin{array}{l}\text { Ability to } \\
\text { classify } \\
\text { NSCLC } \\
\text { subtype }\end{array}$ & $\begin{array}{l}\text { IHC significantly lowers rate of } \\
\text { NOS }\end{array}$ & Good \\
\hline $\begin{array}{l}\text { Gauchotte } \\
{[41]} \\
2012\end{array}$ & $\begin{array}{l}\text { Retrospective, } \\
\text { observational } \\
\text { cohort study }\end{array}$ & $\begin{array}{l}\text { Patients with } \\
\text { mediastinal } \\
\text { NSCLC diagnosed } \\
\text { by EBUS-TBNA }\end{array}$ & $\begin{array}{l}\text { Combination } \\
\text { of CB, } \\
\text { cytology and } \\
\text { LBC }\end{array}$ & $\begin{array}{l}\text { Smear } \\
\text { diagnosis } \\
\text { alone }\end{array}$ & $\begin{array}{l}\text { Diagnostic } \\
\text { yield }\end{array}$ & $\begin{array}{l}\text { Combination of smear cytology, } \\
\text { LBC and CBP maximized Dx yield; } \\
\text { smears and LBC, used without } \\
\text { CBP, increase the risk of a } \\
\text { false-negative result }\end{array}$ & Fair \\
\hline $\begin{array}{l}\text { Natu } \\
{[42]} \\
2010\end{array}$ & $\begin{array}{l}\text { Comparison of } \\
\text { retrospective } \\
\text { cohorts }\end{array}$ & $\begin{array}{l}\text { EBUS-TBNA } \\
\text { staging of NSCLC }\end{array}$ & $\begin{array}{l}\text { LBC } \\
\text { (CytycT2000 } \\
\text { processing } \\
\text { unit) }\end{array}$ & $\begin{array}{l}\text { Pap. } \\
\text { (conventional) }\end{array}$ & & $\begin{array}{l}\text { Overall inadequate specimen rate } \\
12 \% ; 16.6 \% \text { for conventional } \\
\text { method, } 17.2 \% \text { when both } \\
\text { conventional and LBC and } 9.8 \% \\
\text { with LBC }\end{array}$ & Poor \\
\hline
\end{tabular}

$\mathrm{CB}=$ Cell block; $\mathrm{CBP}=\mathrm{CB}$ preparations; $\mathrm{Dx}=$ diagnosis $\mathrm{LBC}=$ liquid-based cytology; NSCLC $=$ non-small cell lung cancer; NSR-CB = normal saline rinse CB method; Pap. = Papanicolaou. 
Table 7. Specimen preparation techniques for conventional TBNA and EBUS-TBNA: summary of evidence, outcome parameters and quality indicators: is there an optimal slide preparation technique?

\begin{tabular}{|c|c|c|c|c|c|c|c|}
\hline $\begin{array}{l}\text { First } \\
\text { author }\end{array}$ & Study design & Population & Intervention & Comparator & $\begin{array}{l}\text { Primary } \\
\text { objective } \\
\text { (endpoint) }\end{array}$ & Outcome & $\begin{array}{l}\text { Quality } \\
\text { metric } \\
\text { indicator }\end{array}$ \\
\hline $\begin{array}{l}\text { Natu } \\
{[42]} \\
2010\end{array}$ & $\begin{array}{l}\text { Comparison } \\
\text { of retrospective } \\
\text { cohorts }\end{array}$ & $\begin{array}{l}\text { EBUS-TBNA } \\
\text { staging of NSCLC }\end{array}$ & $\begin{array}{l}\text { LBC } \\
\text { (CytycT2000 } \\
\text { processing } \\
\text { unit) }\end{array}$ & $\begin{array}{l}\text { Pap. } \\
\text { (conventional) }\end{array}$ & & $\begin{array}{l}\text { Overall inadequate specimen rate } \\
\text { was } 12 \% ; 16.6 \% \text { with the } \\
\text { conventional method, } 17.2 \% \text { when } \\
\text { both conventional and LBC were } \\
\text { used, and } 9.8 \% \text { with LBC; no } \\
\text { statistical analysis performed; } \\
\text { LBC reported to require just } 1 \text { slide } \\
\text { (compared to a median of } 7 \text { with } \\
\text { Pap.) and } 20 \text { min less pathology } \\
\text { reporting time }\end{array}$ & Fair \\
\hline
\end{tabular}

LBC = Liquid-based cytology; Pap. = Papanicolaou; WG = Wright-Giemsa.

preparation may vary between institutions depending on the preferences/expertise of pathology colleagues. We suggest local consultation with pathologists/cytologists to determine their preferred method of specimen preparation.

Multiple methods for slide preparation have been reported, all of which appear to achieve similarly acceptable diagnostic performance. Single reports suggest cost/time/ resource benefits for the use of specific techniques though these require further validation.

\section{Recommendations}

When performing EBUS-TBNA for the diagnosis of lung cancer:

- Where possible, we recommend placing part of the sample in a solution that allows for preparation of cell blocks to facilitate IHC examination for proper subclassification. The solution (e.g. formalin, saline or Hanks' solution) used should be chosen following consultation with local and molecular pathology colleagues. Local practice and pathology preferences will determine the choice between cell block and core tissue preparation.

Grade 2C

- No specific slide preparation technique performs better than others. We recommend local expertise and practice as well institution resources be considered when selecting the slide staining technique.

\section{Results of PICO Question 3}

Among patients with known or suspected lung cancer who undergo conventional TBNA or EBUS-TBNA, does ROSE affect the quantity, quality and yield of the specimens for diagnosis?

We identified 9 subquestions relevant for daily clinical practice regarding the use of ROSE in conventional TBNA and EBUS-TBNA in patients with suspected lung cancer (table 8).

\section{Can ROSE increase the diagnostic yield?}

No.

The only randomized study with enough power to address this question showed that the diagnostic yield and sample adequacy of conventional TBNA was not altered in patients with hilar or mediastinal lymphadenopathy (but the number of biopsy sites and complication rate of bronchoscopy were significantly reduced in the ROSE group) (evidence level A) [47]. In this study, the Diff-Quick staining method was used. In a smaller group of patients with mediastinal or hilar lymphadenopathy, Yarmus et al. [48] found no differences in the diagnostic yield of conventional TBNA, suggesting that ROSE could be reserved for selected patients. However, this study was insufficiently powered to detect smaller but clinically relevant differences in the diagnostic yield 
Table 8. ROSE outcome parameters in randomized trials

\begin{tabular}{|c|c|c|c|c|c|c|c|}
\hline Reference & Study design & Population & Intervention & Comparator & $\begin{array}{l}\text { Primary } \\
\text { objective } \\
\text { (endpoint) }\end{array}$ & Outcome & $\begin{array}{l}\text { Quality } \\
\text { metric } \\
\text { indicator }\end{array}$ \\
\hline $\begin{array}{l}\text { Trisolini } \\
{[47]} \\
2011\end{array}$ & $\begin{array}{l}\text { Prospective, } \\
\text { experimental } \\
\text { RCT }\end{array}$ & $\begin{array}{l}\text { Enlarged } \\
\text { mediastinal or } \\
\text { hilar LN } \\
(\mathrm{n}=168)\end{array}$ & $\begin{array}{l}\text { TBNA + } \\
\text { ROSE } \\
(n=83)\end{array}$ & $\begin{array}{l}\text { TBNA } \\
(\mathrm{n}=85)\end{array}$ & $\begin{array}{l}\text { Diagnostic } \\
\text { yield; } \\
\text { secondary: } \\
\text { biopsy sites }\end{array}$ & $\begin{array}{l}\text { Yield: } 78 \text { vs. } 75 \%(\mathrm{NS}) \\
\text { adequate sample } 78 \text { vs. } 87 \%(\mathrm{NS}) \\
\text { number of TBB (IQR) } 1 \text { vs. } 2(\mathrm{p}<0.001) \text {; } \\
\text { complication rate } 6 \text { vs. } 20 \%(\mathrm{p}<0.05)\end{array}$ & Good \\
\hline $\begin{array}{l}\text { Yarmus } \\
{[48]} \\
2011\end{array}$ & $\begin{array}{l}\text { Prospective, } \\
\text { experimental } \\
\text { RCT }\end{array}$ & $\begin{array}{l}\text { Enlarged } \\
\text { mediastinal or } \\
\text { hilar LN } \\
(\mathrm{n}=68)\end{array}$ & $\begin{array}{l}\text { TBNA + } \\
\text { ROSE } \\
(n=34)\end{array}$ & $\begin{array}{l}\text { TBNA } \\
(\mathrm{n}=34)\end{array}$ & $\begin{array}{l}\text { Diagnostic } \\
\text { yield; } \\
\text { secondary: } \\
\text { number of } \\
\text { needle passes } \\
\text { and } \\
\text { procedure } \\
\text { time }\end{array}$ & $\begin{array}{l}\text { Yield: } 55 \text { vs. } 53 \%(\mathrm{NS}) \text {; } \\
\text { adequate sample } 94 \mathrm{vs.} 88 \%(\mathrm{NS}) \text {; } \\
\text { number of needle passes } 4 \text { vs. } 4 \text { (NS); } \\
\text { number of TBB (NS); procedure duration } \\
\text { time and amount of sedatives needed (NS); } \\
\text { complication rate not reported; study was } \\
\text { powered to detect differences in yield }>30 \%\end{array}$ & Fair \\
\hline $\begin{array}{l}\text { Oki } \\
{[49]} \\
2013\end{array}$ & $\begin{array}{l}\text { Prospective, } \\
\text { experimental } \\
\text { RCT }\end{array}$ & $\begin{array}{l}\text { Enlarged } \\
\text { mediastinal or } \\
\text { hilar } \mathrm{LN}+ \\
\text { (suspected) } \\
\text { lung cancer } \\
(\mathrm{n}=120)\end{array}$ & $\begin{array}{l}\text { EBUS + } \\
\text { ROSE } \\
(n=55)\end{array}$ & $\begin{array}{l}\text { EBUS } \\
(n=53)\end{array}$ & $\begin{array}{l}\text { Number of } \\
\text { additional } \\
\text { procedures }\end{array}$ & $\begin{array}{l}\text { Additional procedures } 11 \text { vs. } 57 \% \text { ( } \mathrm{p}< \\
0.001 \text { ); number of aspirations } 2.2 \text { vs. } 3.1 \\
\text { ( } \mathrm{p}<0.001 \text {; in non-ROSE group } \\
\text { predetermined to } 3 \text { ); procedure time } 22.3 \text { vs. } \\
22.1 \text { min (NS); sensitivity } 88 \text { vs. } 86 \% \text { (NS); } \\
\text { accuracy } 89 \text { vs. } 89 \% \text { (NS) }\end{array}$ & Good \\
\hline $\begin{array}{l}\text { Mondoni } \\
{[73]} \\
2013\end{array}$ & $\begin{array}{l}\text { Prospective, } \\
\text { experimental } \\
\text { RCT }\end{array}$ & $\begin{array}{l}\text { Central } \\
\text { airway } \\
\text { tumors } \\
(\mathrm{n}=125)\end{array}$ & $\begin{array}{l}\text { Endo- } \\
\text { bronchial } \\
\text { needle }+ \\
\text { ROSE } \\
(\mathrm{n}=63)\end{array}$ & $\begin{array}{l}\text { EBNA } \\
(n=62)\end{array}$ & $\begin{array}{l}\text { EBNA vs. } \\
\text { conventional } \\
\text { techniques } \\
\text { (forceps } \\
\text { biopsy, brush } \\
\text { for central } \\
\text { lesions) }\end{array}$ & $\begin{array}{l}\text { No blind TBNA or EBUS used in this study; } \\
\text { sensitivity } 97 \text { vs. } 76 \%(\mathrm{p}<0.01)\end{array}$ & Good \\
\hline $\begin{array}{l}\text { Louw } \\
{[44]} \\
2012\end{array}$ & $\begin{array}{l}\text { Retrospective, } \\
\text { observational }\end{array}$ & $\begin{array}{l}\text { Patients } \\
\text { undergoing } \\
\text { TBNA } \\
(\mathrm{n}=126)\end{array}$ & $\begin{array}{l}\text { WG stain } \\
+ \text { ROSE } \\
\text { (1 operator) }\end{array}$ & $\begin{array}{l}\text { WG + Pap. } \\
+ \text { ROSE } \\
\text { ( } 2 \text { operators })\end{array}$ & $\begin{array}{l}\text { Diagnostic } \\
\text { yield }\end{array}$ & $\begin{array}{l}\text { Staining method of ROSE did not } \\
\text { significantly influence the quantity or } \\
\text { quality of the material submitted for } \\
\text { laboratory analysis and makes the process of } \\
\text { ROSE more costly and labor-intensive }\end{array}$ & Poor \\
\hline $\begin{array}{l}\text { Nakajima } \\
{[53]} \\
2013\end{array}$ & $\begin{array}{l}\text { Retrospective, } \\
\text { observational }\end{array}$ & $\begin{array}{l}\text { Suspected or } \\
\text { diagnosed } \\
\text { lung cancer, } \\
\text { for staging } \\
(\mathrm{n}=438)\end{array}$ & $\begin{array}{l}\text { EBUS- } \\
\text { TBNA + } \\
\text { ROSE }\end{array}$ & None & $\begin{array}{l}\text { To assess the } \\
\text { role of ROSE } \\
\text { for EBUS }\end{array}$ & $\begin{array}{l}\text { Concordance rate between ROSE and final } \\
\text { EBUS-TBNA in staging lung cancer } 94.3 \% \text {; } \\
\text { no false positive by ROSE; } \\
5.7 \% \text { false negative by ROSE; } \\
\text { Diff-Quick was used for ROSE, additional } \\
\text { Pap. for final cytology result }\end{array}$ & Good \\
\hline $\begin{array}{l}\text { Diacon } \\
{[51]} \\
2005\end{array}$ & $\begin{array}{l}\text { Prospective } \\
\text { cohort }\end{array}$ & $\begin{array}{l}110 \text { patients } \\
\text { with enlarged } \\
\text { LN or } \\
\text { peribronchial } \\
\text { or peripheral } \\
\text { lesions }\end{array}$ & $\begin{array}{l}\text { TBNA + } \\
\text { ROSE }\end{array}$ & $\begin{array}{l}\text { Hypothetical } \\
\text { procedure } \\
\text { without } \\
\text { ROSE }\end{array}$ & $\begin{array}{l}\text { Cost balance; } \\
\text { time balance }\end{array}$ & $\begin{array}{l}\text { Cost balance was in favor of ROSE; } \\
\text { time balance was in favor of ROSE for every } \\
\text { operator (bronchoscopist, nurse and } \\
\text { administrative personnel) but the } \\
\text { pathologist }\end{array}$ & Fair \\
\hline $\begin{array}{l}\text { Collins } \\
{[52]} \\
2013\end{array}$ & $\begin{array}{l}\text { Retrospective, } \\
\text { matched } \\
\text { cohort }\end{array}$ & $\begin{array}{l}680 \text { patients } \\
\text { from database } \\
\text { (no details } \\
\text { provided) }\end{array}$ & $\begin{array}{l}\text { EBUS + } \\
\text { ROSE; } \\
\text { comparison } \\
\text { before vs. } \\
\text { after ROSE } \\
\text { introduction }\end{array}$ & $\begin{array}{l}\text { Matched } \\
\text { historical } \\
\text { group } \\
\text { without } \\
(\mathrm{n}=340) \text { and } \\
\text { with ROSE } \\
(\mathrm{n}=340)\end{array}$ & $\begin{array}{l}\text { Impact on } \\
\text { biopsy } \\
\text { procedure and } \\
\text { impact of the } \\
\text { ROSE service } \\
\text { on the } \\
\text { procedure and } \\
\text { utilization of } \\
\text { laboratory } \\
\text { resources }\end{array}$ & $\begin{array}{l}\text { Number of biopsy sites reduced from } 2.1 \text { to } \\
1.4 \text { per patient with ROSE ( } 33 \% \text { reduction; } \\
\mathrm{p}<0.001 \text { ); } \\
\text { number of slides per patient reduced with } \\
\text { ROSE from } 17.6 \text { to } 12.3 \text { per patient (mean } \\
\text { reduction of } 5.3 \text { per patient; } \mathrm{p}<0.001 \text { ); } \\
\text { remarkably, the number of slides per site } \\
\text { remained unchanged ( } 8.4 \text { vs. } 8.8 \text { ); } \\
\text { the calculated estimated reduction in time } \\
\text { spent as a result of ROSE: } 149 \text { h for } \\
\text { cytotechnicians, } 90 \text { h for cytopathologists } \\
\text { and } 59 \text { h of EBUS time }\end{array}$ & Fair \\
\hline
\end{tabular}

Pap. = Papanicolaou; $\mathrm{TBB}=$ transbronchial biopsy; $\mathrm{WG}=$ Wright-Giemsa . 
between the two groups [48]. A recently performed RCT on EBUS-TBNA by Oki et al. [49] was also, unfortunately, underpowered. Finally, the study of Mondoni et al. [73] was not blinded and focused on patients with centrally located lung cancer, but showed that ROSE improved the sensitivity from 76 to $97 \%$. Of note, although both the study of Trisolini et al. [47] and the study of Yarmus et al. [48] did not solely study patients with (suspected) lung cancer but contained approximately $30 \%$ other diagnoses, we feel that this is of minor influence in relation to this PICO question.

\section{Can ROSE decrease the number of aspirations?}

No.

Again, only one RCT showed that the number of needle aspirations (i.e. entering the needle into the target lesion and moving it from the proximal to the distal side of the lesion a number of times) was lower in the ROSE group (2.2 vs. 3.1) [49]. The other RCT did not find a difference, but we should note that in the non-ROSE group the number of aspirates was predetermined as 3-4 based on the publications by Lee et al. [7] and Diacon et al. [8], with a plateau in the yield after this number.

\section{Can ROSE decrease procedure time?}

No.

Trisolini et al. [47] showed that procedure time (scope in to scope out) was longer in the ROSE group (although this was not a predetermined endpoint of the trial). The other two RCT showed no difference [48, 49].

Can ROSE reduce the number of additional procedures? Yes.

The feedback of ROSE may reduce the number of additional procedures, especially in case of a first diagnostic procedure. This was found in the studies by Trisolini et al. [47] and Oki et al. [49]. This finding is supported by the analysis of the multicenter registry for EBUS complications by Eapen et al. [50]. It is, however, of importance to stress that different interpretations are available for defining additional procedures. Our committee feels that this statement is valid in case of initial diagnostic procedures: for example, a patient in whom TBNA ROSE confirms a diagnosis of LN metastasis preventing further transbronchial biopsies and/or brushes or washings of the suspected primary tumor. We feel that in an EBUS procedure aimed for staging, ROSE may reduce the number of LN regions that need to be sampled (or targets). EBUS sampling must be initiated at $\mathrm{N} 3$ regions, followed by $\mathrm{N} 2$ and $\mathrm{N} 1$ regions. If
ROSE indicates the presence of metastasis in N3 or N2 $\mathrm{LN}$, additional sampling of further regions (i.e. additional targets) is not necessary and can be omitted. However, the studies mentioned above did not investigate this specific issue $[47,49,50]$. In the study by Oki et al. [49], approximately $50 \%$ of the additional targets were registered as an additional procedure, but details on how initial targets were defined are missing and may be subject to bias. We recommend that this issue should be studied further.

\section{Can ROSE reduce the rate of complications?}

No.

ROSE does not influence the immediate risk of EBUS or conventional TBNA. Nevertheless, since ROSE may reduce the number of additional procedures and especially the need for transbronchial biopsies, complications associated with these additional procedures may be decreased by ROSE $[47,50]$.

\section{Is ROSE cost-effective?}

There is no significant evidence for or against the cost effectiveness of ROSE. One prospective cohort study in 110 patients with enlarged LN (78\% suspected malignant) reported that ROSE may reduce total costs and time requirements for all involved professionals (except the pathology professionals) [51]. In a patient-matched case-control study of 680 patients, the use of ROSE reduced the number of sites biopsied by $33 \%$ [52]. There was a 30\% decrease in total slides (mean reduction of 5.3 slides/patient), which had a significant impact on the calculated cytopathology laboratory work effort and resource utilization [52].

What is the concordance rate of ROSE with the final diagnosis?

The concordance is high. In the RCT by Trisolini et al. [47], a concordance of $89.1 \%$ was found between ROSE and the final diagnosis, and in the retrospective observational trial by Nakajima et al. [53], concordance was $94.3 \%$. No false-positive results were found for ROSE, and the false-negative rate varied between 4.8 and 5.7\% [47, 53].

\section{Is there an optimal staining method for ROSE?}

There are insufficient data to answer this question. Diff-Quick was used in the majority of studies for on-site evaluation [47-49]. For definitive analysis, often a second slide is fixed for Papanicolaou staining. One study compared ROSE performed with Wright-Giemsa staining versus ROSE with Papanicolaou staining and did not find a significant difference in the yield [44]. 
Who needs to perform ROSE (pathologists, cytopathologists, cytotechnicians, pulmonologists or trained nurses)?

This question cannot be answered based on the available literature. Local procedures vary extensively as reflected in the available studies. A recent observational trial did provide preliminary evidence that a pulmonologist can perform, after a short yet intensive training phase, ROSE to assess the adequacy of conventional TBNA samples from hilar/mediastinal LN with accuracy similar to that of a board-certified cytopathologist [54].

\section{Summary}

Although most large centers with high volume and vast experience in TBNA/EBUS-TBNA utilize ROSE in their daily clinical practice, the effect of ROSE itself has not been adequately studied. While ROSE offers the possibility of immediate and accurate feedback on the diagnosis and quality of the obtained specimen with the potential to influence the operator's plan (i.e. obtain additional samples for molecular testing, samples for culture or samples for flow cytometry), its use is not supported by firm evidence but still highly recommended by our expert consensus. ROSE is highly concordant with the final diagnosis and it may reduce the number of additional diagnostic procedures needed (and the risks associated with those procedures), but it does not influence the complication rate of EBUS or TBNA itself. The number of aspirations needed may be reduced, but procedure time has not been shown to be altered. There are insufficient data to evaluate cost effectiveness and to determine who should perform ROSE. Most studies used Diff-Quick as staining; no comparative data are available.

\section{Recommendations}

In patients with suspected lung cancer and enlarged mediastinal or hilar LN and/or centrally located tumors:

- Evidence is insufficient to recommend that ROSE be used in every procedure. Grade $1 b$

\section{Results of PICO Question 4}

Among patients with known lung cancer, do conventional TBNA and EBUS-TBNA acquisition techniques (as described in PICO 1), specimen preparation techniques (as described in PICO 2) or ROSE (as described in PICO 3) affect the ability to perform molecular testing (i.e. EGFR/

EBUS and TBNA Specimen Handling Guideline
ALK but also other markers with predictive/prognostic information, such as KRAS, ERCC1, RRM1, TS, PIK3CA and MET)?

Molecular analysis can be routinely performed on the majority of cytological samples obtained by EBUS-TBNA and conventional TBNA but largely depends on the absolute number of tumor cells (preferably $>100$ ), the percentage of tumor cells present in the material, the degree of preservation of tumor cells, and the type and sensitivity of the molecular test that is being utilized $[46,55,56]$. In general, the material obtained by EBUS-TBNA is suitable for molecular analysis, which can be performed in $88-96 \%$ of the samples [38, 57-59].

Do conventional TBNA and EBUS-TBNA acquisition techniques affect the ability to perform molecular testing?

A recent study by Yarmus et al. [60] examined the number of EBUS-TBNA aspirations (using a 21-gauge needle and ROSE) required to ensure maximal diagnostic yield for mutational analysis. This retrospective study noted that specimens were adequate for molecular analysis in $95 \%$ of all cases with a median number of 4 aspirations [60]. Ulivi et al. [61] demonstrated the possibility to perform molecular analysis of EGFR mutations and ALK rearrangement by fluorescence in situ hybridization (FISH) on the same slide, first testing FISH and then microdissecting tumor cells for EGFR extractive molecular determination. Other sources of tumor cells are needle washings. A comparison of the results obtained from molecular testing of EGFR and KRAS mutations on needle washing tumor cells and conventional smears demonstrated identical molecular data [62]. It is unclear as to whether as little as 1 aspirate is adequate, or whether the same finding would be observed with the use of the more commonly used 22 -gauge needle.

We have found no evidence regarding the influence of the type of the needle, use of miniforceps, suctioning and type of sedation, time spent inside the node and number of revolutions inside the node with regard to molecular testing of lung cancer.

Do conventional TBNA and EBUS-TBNA specimen preparation techniques (core tissue/cell block) affect the ability to perform molecular testing?

No study has directly compared one technique versus the other with regard to molecular testing.

da Cunha Santos et al. [63] reported a systematic review for EGFR mutation testing using cytological sam- 
ples. Different techniques using cell blocks, scraped cells from archival slides and fresh cells were used for EGFR gene status testing, and their results were compared to those from surgically resected specimens. The results were similar or even higher for cytological samples showing that EGFR mutation testing can be easily performed with these specimens.

For EGFR mutation testing, there are several retrospective analyses with prospective sample collection. Horiike et al. [64] employed conventional TBNA samples for EGFR mutation testing. They enrolled 94 patients with NSCLC (58 adenocarcinomas, 24 squamous cell carcinomas and 12 patients with other types of NSCLC), and the aspirate was mixed with $2 \mathrm{ml}$ of saline solution and stored at $-80^{\circ} \mathrm{C}$ until DNA extraction. They performed both direct sequencing and a highly sensitive assay (Scorpions amplified refractory mutation system; DxS, Manchester, UK), and they compared the sensitivity of these methods. They concluded the Scorpions amplified refractory mutation system was more sensitive than direct sequencing to detect EGFR mutations using TBNA samples [64].

Nakajima et al. [65] and Garcia-Olive et al. [66] reported EGFR mutation testing using EBUS-TBNA samples. Nakajima et al. [65] were able to test all the samples for mutational analysis and Garcia-Olive et al. [66] reported $72.2 \%$ of the samples were feasible for the analysis.

The results of multigene mutation testing were also reported as retrospective analysis. This could also be successfully performed in research settings $[65,67]$ and daily clinical practice $[38,43]$. Multigene mutation testing could be performed in 77\% of cases for EGFR and KRAS [43], in $82 \%$ of cases for EGFR, KRAS and EML4-ALK FISH [68] and 95, 91 and 91\% for EGFR, KRAS and EML4-ALK FISH, respectively [59].

To detect ALK fusion genes, one report used fine needle aspirates in 17 of 41 samples studied (41\%) for ALK FISH and IHC [69]. No details, however, were presented on the acquisition technique (conventional or EBUS-TBNA). There are two retrospective studies using EBUS-TBNA samples [70, 71]. One study utilized 'core' samples and referenced frozen-stored samples for IHC, FISH and RT-PCR [70]. Another study used cell blocks for FISH and IHC [71]. ALK fusion genes could be detected using EBUS-TBNA-derived cytological samples.

RNA-based testing remains experimental and the reported data are very limited. When RNA isolated from TBNA samples is used, the quality of RNA is critical and special attention should be paid to the storage of the sample to avoid RNA degeneration. EBUS-TBNA samples can be used for RNA-based analysis, and we can obtain enough amount and quality of RNA in a well-controlled setting. The RNA isolated from EBUS-TBNA samples can be used for comprehensive gene expression analysis using microarray technology $[65,72]$.

Does ROSE influence tissue sampling for molecular analysis?

ROSE is very useful for the confirmation of the presence of tumor cells within the samples. Even though no prospective comparative trials have been published on the possible influence of ROSE on the diagnostic yield of TBNA or EBUS-TBNA for molecular testing, we suggest that ROSE be used when molecular testing is looked for until high-quality trials are available. Currently, an RCT aimed at evaluating the role of ROSE in EBUS-TBNA samples for molecular testing is ongoing (ClinicalTrials. gov identifier: NCT01799382).

\section{Summary}

Molecular analysis can be routinely performed on the majority of cytological samples obtained by EBUS-guided and conventional TBNA but largely depends on the absolute number of vital tumor cells, percentage of tumor cells present in the material and the sensitivity of the molecular test that is being utilized.

Although there is no prospective study evaluating the number of passes required to obtain adequate specimens for molecular testing, it appears that a number of 4 passes should suffice. There are no data regarding the influence of the type of the needle, use of miniforceps, suctioning, type of sedation, time spent inside the node and number of revolutions inside the node on molecular testing.

Both smear and cell block preparations or core tissue can be utilized for molecular testing (while cell blocks and core tissue represent the best material for mutational analysis and are indispensable at the moment to assess ALK translocation, cytological slides can be successfully used to determine the status of EGFR and KRAS in cases where cell blocks or core tissue are lacking or feature an insufficient burden of tumor cells). A prospective trial is being conducted in regard to the influence of ROSE on molecular analysis. Until results are available, we suggest that ROSE be used when molecular testing is needed, to corroborate a large tumor burden in the sample (expert opinion). 


\section{Recommendations}

Regarding conventional TBNA or EBUS-TBNA for molecular testing of lung cancer:

- A total of 4 passes should be obtained from the target whenever molecular testing is planned. Grade $2 \mathrm{C}$

- Smears, cell block or core tissue preparation can be utilized for molecular testing. Grade $2 \mathrm{C}$

- ROSE should be utilized when available to evaluate tumor burden in target samples. Grade 2C

\section{Conclusion}

Conventional TBNA and particularly EBUS-TBNA have become first-line tools for the staging and diagnosis of patients with (suspected) lung cancer. Hence, adequate specimen acquisition and handling are of critical importance to correctly diagnose and stage lung cancer. A precise diagnosis (histological subtype) and molecular testing on these specimens are key to choosing the optimal treatment regimen for these patients. With this guideline, we aim to aid both starting and more experienced centers in interventional pulmonary medicine worldwide hopefully leading to a global unification of procedure standards, maximization of conventional TBNA and EBUSTBNA yield, and identification of areas where research is needed.

\section{Acknowledgments}

We would like to thank the members of the WABIP executive committee: Jean-Michel Vergnon (France), Takehiko Fujisawa (Japan), James Jett (USA) and Henri Colt (USA) for their help and support to organize this Task Force; Michel Mendoza (administrator at WABIP) for his help in organizing the meetings and Alice Tillema (librarian at the Radboud University Nijmegen, The Netherlands) for her help in building the literature search strategies.

\section{Financial Disclosure and Conflicts of Interest}

Conflict of interest statements have been obtained by WABIP prior to the start of the project of all members involved.

\section{References}

-1 Rivera MP, Mehta AC, Wahidi MM: Establishing the diagnosis of lung cancer: diagnosis and management of lung cancer, 3rd ed: American College of Chest Physicians evidence-based clinical practice guidelines. Chest 2013;143:e142S-e165S.

$\checkmark 2$ Kinsey CM, Arenberg DA: Endobronchial ultrasound-guided transbronchial needle aspiration for non-small cell lung cancer staging. Am J Respir Crit Care Med 2014;189:640649.

$>3$ De Leyn P, Dooms C, Kuzdzal J, Lardinois D, Passlick B, Rami-Porta R, Turna A, Van Schil P, Venuta F, Waller D, Weder W, Zielinski M: Revised ESTS guidelines for preoperative mediastinal lymph node staging for non-smallcell lung cancer. Eur J Cardiothorac Surg 2014;45:787-798

4 Rami-Porta R, Wittekind C, Goldstraw P; International Association for the Study of Lung Cancer (IASLC) Staging Committee: Complete resection in lung cancer surgery: proposed definition. Lung Cancer 2005;49:2533.

5 Verhagen AF, Schoenmakers MC, Barendregt W, Smit H, van Boven WJ, Looijen M, van der Heijden EH, van Swieten HA: Completeness of lung cancer surgery: is mediastinal dissection common practice? Eur J Cardiothorac Surg 2012;41:834-838.

6 Bulman W, Saqi A, Powell CA: Acquisition and processing of endobronchial ultrasound- guided transbronchial needle aspiration specimens in the era of targeted lung cancer chemotherapy. Am J Respir Crit Care Med 2012; 185:606-611.

7 Lee HS, Lee GK, Lee HS, Kim MS, Lee JM, Kim HY, Nam BH, Zo JI, Hwangbo B: Realtime endobronchial ultrasound-guided transbronchial needle aspiration in mediastinal staging of non-small cell lung cancer: how many aspirations per target lymph node station? Chest 2008;134:368-374.

$>8$ Diacon AH, Schuurmans MM, Theron J, Brundyn K, Louw M, Wright CA, Bolliger CT: Transbronchial needle aspirates: how many passes per target site? Eur Respir J 2007;29: $112-116$.

-9 Chin R Jr, McCain TW, Lucia MA, Cappellari JO, Adair NE, Lovato JF, Dunagan DP, Brooks MA, Clark HP, Haponik EF: Transbronchial needle aspiration in diagnosing and staging lung cancer: how many aspirates are needed? Am J Respir Crit Care Med 2002;166:377381.

10 Oki M, Saka H, Kitagawa C, Kogure Y, Murata N, Ichihara S, Moritani S, Ando M: Randomized study of 21-gauge versus 22-gauge endobronchial ultrasound-guided transbronchial needle aspiration needles for sampling histology specimens. J Bronchology Interv Pulmonol 2011;18:306-310.

11 Yarmus LB, Akulian J, Lechtzin N, Yasin F, Kamdar B, Ernst A, Ost DE, Ray C, Greenhill
SR, Jimenez CA, Filner J, Feller-Kopman D; American College of Chest Physicians Quality Improvement Registry, Education, and Evaluation (AQuIRE) Participants: Comparison of 21-gauge and 22-gauge aspiration needle in endobronchial ultrasound-guided transbronchial needle aspiration: results of the American College of Chest Physicians Quality Improvement Registry, Education, and Evaluation Registry. Chest 2013;143: 1036-1043.

12 Nakajima T, Yasufuku K, Takahashi R, Shingyoji M, Hirata T, Itami M, Matsui Y, Itakura M, Iizasa T, Kimura H: Comparison of 21gauge and 22-gauge aspiration needle during endobronchial ultrasound-guided transbronchial needle aspiration. Respirology 2011;16: 90-94.

13 Saji J, Kurimoto N, Morita K, Nakamura M, Inoue T, Nakamura H, Miyazawa T: Comparison of 21-gauge and 22-gauge needles for endobronchial ultrasound-guided transbronchial needle aspiration of mediastinal and hilar lymph nodes. J Bronchology Interv Pulmonol 2011;18:239-246.

14 Schenk DA, Chambers SL, Derdak S, Komadina KH, Pickard JS, Strollo PJ, Lewis RE, Patefield AJ, Henderson JH, Tomski SM, et al: Comparison of the Wang 19-gauge and 22-gauge needles in the mediastinal staging of lung cancer. Am Rev Respir Dis 1993;147: 1251-1258. 
-15 Harrow EM, Abi-Saleh W, Blum J, Harkin T, Gasparini S, Addrizzo-Harris DJ, Arroliga AC, Wight G, Mehta AC: The utility of transbronchial needle aspiration in the staging of bronchogenic carcinoma. Am J Respir Crit Care Med 2000;161:601-607.

- 16 Stratakos G, Porfyridis I, Papas V, Kandaraki C, Zisis C, Mariatou V, Liapikou A, Roussos C, Zakynthinos S: Exclusive diagnostic contribution of the histology specimens obtained by 19 -gauge transbronchial aspiration needle in suspected malignant intrathoracic lymphadenopathy. Chest 2008;133:131-136.

-17 Ceron L, Michieletto L, Pagan V, Zamperlin A: Transbronchial needle aspiration in patients with mediastinal and hilar disease. J Bronchol 2007;14:6-9.

18 Chrissian A, Misselhorn D, Chen A: Endobronchial-ultrasound guided miniforceps biopsy of mediastinal and hilar lesions. Ann Thorac Surg 2011;92:284-288.

-19 Franke KJ, Bruckner C, Szyrach M, Ruhle KH, Nilius G, Theegarten D: The contribution of endobronchial ultrasound-guided forceps biopsy in the diagnostic workup of unexplained mediastinal and hilar lymphadenopathy. Lung 2012;190:227-232.

20 Darwiche K, Freitag L, Nair A, Neumann C, Karpf-Wissel R, Welter S, Wohlschlaeger J, Theegarten D: Evaluation of a novel endobronchial ultrasound-guided lymph node forceps in enlarged mediastinal lymph nodes. Respiration 2013;86:229-236.

-21 Herth FJ, Morgan RK, Eberhardt R, Ernst A: Endobronchial ultrasound-guided miniforceps biopsy in the biopsy of subcarinal masses in patients with low likelihood of non-small cell lung cancer. Ann Thorac Surg 2008;85 1874-1878.

-22 Herth FJ, Schuler H, Gompelmann D, Kahn N, Gasparini S, Ernst A, Schuhmann M, Eberhardt R: Endobronchial ultrasoundguided lymph node biopsy with transbronchial needle forceps: a pilot study. Eur Respir J 2012;39:373-377.

-23 Tremblay A, Stather DR, Maceachern P, Khalil M, Field SK: A randomized controlled trial of standard vs. endobronchial ultrasonography-guided transbronchial needle aspiration in patients with suspected sarcoidosis. Chest 2009;136:340-346.

24 Wong M, Yasufuku K, Nakajima T, Herth FJ, Sekine Y, Shibuya K, Iizasa T, Hiroshima K, Lam WK, Fujisawa T: Endobronchial ultrasound: new insight for the diagnosis of sarcoidosis. Eur Respir J 2007;29:1182-1186.

-25 Garwood S, Judson MA, Silvestri G, Hoda R, 36 Fraig M, Doelken P: Endobronchial ultrasound for the diagnosis of pulmonary sarcoidosis. Chest 2007;132:1298-1304.

26 Wang JF, Baidoo C, Collins BT: Improved efficacy of endobronchial ultrasound-guided fine-needle aspiration biopsy in comparison to endobronchial ultrasound-guided miniforceps biopsy. Acta Cytol 2014;58:125-130.

-27 Casal RE, Staerkel GA, Ost D, Almeida FA, Uzbeck MH, Eapen GA, Jimenez CA, No-
gueras-Gonzalez GM, Sarkiss M, Morice RC: Randomized clinical trial of endobronchial ultrasound needle biopsy with and without aspiration. Chest 2012;142:568-573.

28 Boonsarngsuk V, Pongtippan A, Juthakarn S: The effect of aspiration pressure over endobronchial ultrasound-guided transbronchial needle aspiration on the diagnosis of intrathoracic lymphadenopathies. Lung 2013;191: 435-440.

29 Rodriguez F, Seijo LM, Sanchez PA, Zulueta $\mathrm{JJ}$ : Modified technique for obtaining mediastinal samples with endobronchial ultrasoundguided transbronchial needle aspiration: results from a prospective observational study. Arch Bronconeumol 2013;49:135-139.

-30 Yarmus LB, Akulian JA, Gilbert C, Mathai SC, Sathiyamoorthy S, Sahetya S, Harris K, Gillespie C, Haas A, Feller-Kopman D, Sterman D, Lee HJ: Comparison of moderate versus deep sedation for endobronchial ultrasound transbronchial needle aspiration. Ann Am Thorac Soc 2013;10:121-126.

31 DePew ZS, Edell ES, Midthun DE, Mullon JJ, Bungum AO, Decker PA, Maldonado F; Mayo Pulmonary Procedural Group: Endobronchial ultrasound-guided transbronchial needle aspiration: determinants of sampling adequacy. J Bronchology Interv Pulmonol 2012;19:271-276.

32 Ost DE, Ernst A, Lei X, Feller-Kopman D, Eapen GA, Kovitz KL, Herth FJ, Simoff M, AQuIRE Bronchoscopy Registry: Diagnostic yield of endobronchial ultrasound-guided transbronchial needle aspiration: results of the AQuIRE Bronchoscopy Registry. Chest 2011;140:1557-1566.

33 Yung RCW, Otell S, Illei P, Clark DP, FellerKopman D, Yarmus L, Askin F, Gabrielson E, Li QK: Improvement of cellularity on cell block preparations using the so-called tissue coagulum clot method during endobronchial ultrasound-guided transbronchial fine-needle aspiration. Cancer Cytopathol 2012;120: 185-195.

34 Sanz-Santos J, Serra P, Andreo F, Llatjos M, Castella E, Monso E: Contribution of cell blocks obtained through endobronchial ultrasound-guided transbronchial needle aspiration to the diagnosis of lung cancer. BMC Cancer 2012;12:34.

35 Amin EN, Russell CD, Shilo K, Islam S, Wood KL: Diagnostic value of blood clot core during endobronchial ultrasound-guided transbronchial needle aspirate. Lung 2013;191:305309.

36 Wallace WA, Rassl DM: Accuracy of cell typing in nonsmall cell lung cancer by EBUS/ EUS-FNA cytological samples. Eur Respir J 2011;38:911-917.

37 Tournoy KG, Carprieaux M, Deschepper E, van Meerbeeck JP, Praet M: Are EUS-FNA and EBUS-TBNA specimens reliable for subtyping non-small cell lung cancer? Lung Cancer 2012;76:46-50.

38 Navani N, Brown JM, Nankivell M, Woolhouse I, Harrison RN, Jeebun V, Munavvar
M, Ng BJ, Rassl DM, Falzon M, Kocjan G, Rintoul RC, Nicholson AG, Janes SM: Suitability of endobronchial ultrasound-guided transbronchial needle aspiration specimens for subtyping and genotyping of non-small cell lung cancer: a multicenter study of 774 patients. Am J Respir Crit Care Med 2012; 185:1316-1322.

39 Steinfort DP, Russell PA, Tsui A, White G, Wright $G$, Irving LB: Interobserver agreement in determining non-small cell lung cancer subtype in specimens acquired by EBUSTBNA. Eur Respir J 2012;40:699-705.

40 Alici IO, Demirci NY, Yilmaz A, Demirag F, Karakaya J: The combination of cytological smears and cell blocks on endobronchial ultrasound-guided transbronchial needle aspirates allows a higher diagnostic yield. Virchows Arch 2013;462:323-327.

41 Gauchotte G, Vignaud JM, Menard O, Wissler MP, Martinet Y, Siat J, Paris C, ClementDuchene C: A combination of smears and cell block preparations provides high diagnostic accuracy for endobronchial ultrasound-guided transbronchial needle aspiration. Virchows Arch 2012;461:505-512.

42 Natu S, Hoffman J, Siddiqui M, Hobday C, Shrimankar J, Harrison R: The role of endobronchial ultrasound guided transbronchial needle aspiration cytology in the investigation of mediastinal lymphadenopathy and masses, the North Tees experience. J Clin Pathol 2010; 63:445-451.

43 Schuurbiers OC, Looijen-Salamon MG, Ligtenberg MJ, van der Heijden HF: A brief retrospective report on the feasibility of epidermal growth factor receptor and KRAS mutation analysis in transesophageal ultrasound- and endobronchial ultrasound-guided fine needle cytological aspirates. J Thorac Oncol 2010;5:1664-1667.

44 Louw M, Brundyn K, Schubert PT, Wright CA, Bolliger CT, Diacon AH: Comparison of the quality of smears in transbronchial fineneedle aspirates using two staining methods for rapid on-site evaluation. Diagn Cytopathol 2012;40:777-781.

45 Travis WD, Brambilla E, Noguchi M, Nicholson AG, Geisinger K, Yatabe Y, Ishikawa Y, Wistuba I, Flieder DB, Franklin W, Gazdar A, Hasleton PS, Henderson DW, Kerr KM, Petersen I, Roggli V, Thunnissen E, Tsao M: Diagnosis of lung cancer in small biopsies and cytology: implications of the 2011 International Association for the Study of Lung Cancer/American Thoracic Society/European Respiratory Society classification. Arch Pathol Lab Med 2013;137:668-684.

46 Thunnissen E, Kerr KM, Herth FJ, Lantuejoul S, Papotti M, Rintoul RC, Rossi G, Skov BG, Weynand B, Bubendorf L, Katrien G, Johansson L, Lopez-Rios F, Ninane V, Olszewski W, Popper H, Jaume S, Schnabel P, Thiberville L, Laenger F: The challenge of NSCLC diagnosis and predictive analysis on small samples. Practical approach of a working group. Lung Cancer 2012;76:1-18. 
-47 Trisolini R, Cancellieri A, Tinelli C, Paioli D, Scudeller L, Casadei GP, Parri SF, Livi V, Bondi A, Boaron M, Patelli M: Rapid on-site evaluation of transbronchial aspirates in the diagnosis of hilar and mediastinal adenopathy: a randomized trial. Chest 2011;139:395-401.

- 48 Yarmus L, Van der Kloot T, Lechtzin N, Napier M, Dressel D, Feller-Kopman D: A randomized prospective trial of the utility of rapid on-site evaluation of transbronchial needle aspirate specimens. J Bronchology Interv Pulmonol 2011;18:121-127.

-49 Oki M, Saka H, Kitagawa C, Kogure Y, Murata N, Adachi T, Ando M: Rapid on-site cytologic evaluation during endobronchial ultrasound-guided transbronchial needle aspiration for diagnosing lung cancer: a randomized study. Respiration 2013;85:486-492.

50 Eapen GA, Shah AM, Lei X, Jimenez CA, Morice RC, Yarmus L, Filner J, Ray C, Michaud G, Greenhill SR, Sarkiss M, Casal R, Rice D, Ost DE; American College of Chest Physicians Quality Improvement Registry, Education: Complications, consequences, and practice patterns of endobronchial ultrasound-guided transbronchial needle aspiration: results of the AQuIRE registry. Chest 2013;143:1044-1053.

51 Diacon AH, Schuurmans MM, Theron J, Louw M, Wright CA, Brundyn K, Bolliger CT: Utility of rapid on-site evaluation of transbronchial needle aspirates. Respiration 2005; $72: 182-188$.

52 Collins BT, Chen AC, Wang JF, Bernadt CT, Sanati S: Improved laboratory resource utilization and patient care with the use of rapid on-site evaluation for endobronchial ultrasound fine-needle aspiration biopsy. Cancer Cytopathol 2013;121:544-551.

- 53 Nakajima T, Yasufuku K, Saegusa F, Fujiwara T, Sakairi Y, Hiroshima K, Nakatani Y, Yoshino I: Rapid on-site cytologic evaluation during endobronchial ultrasound-guided transbronchial needle aspiration for nodal staging in patients with lung cancer. Ann Thorac Surg 2013;95:1695-1699.

- 54 Bonifazi M, Sediari M, Ferretti M, Poidomani G, Tramacere I, Mei F, Zuccatosta L, Gasparini S: The role of the pulmonologist in rapid on-site cytologic evaluation of transbronchial needle aspiration: a prospective study. Chest 2014;145:60-65.

55 Pao W, Ladanyi M: Epidermal growth factor receptor mutation testing in lung cancer: searching for the ideal method. Clin Cancer Res 2007;13:4954-4955.
6 Lindeman NI, Cagle PT, Beasley MB, Chitale DA, Dacic S, Giaccone G, Jenkins RB, Kwiatkowski DJ, Saldivar JS, Squire J, Thunnissen E, Ladanyi M; College of American Pathologists International Association for the Study of Lung Cancer and Association for Molecular Pathology: Molecular testing guideline for selection of lung cancer patients for EGFR and ALK tyrosine kinase inhibitors: guideline from the College of American Pathologists, International Association for the Study of Lung Cancer, and Association for Molecular Pathology. J Mol Diagn 2013;15:415-453.

57 Esterbrook G, Anathhanam S, Plant PK: Adequacy of endobronchial ultrasound transbronchial needle aspiration samples in the subtyping of non-small cell lung cancer. Lung Cancer 2013;80:30-34.

58 Billah S, Stewart J, Staerkel G, Chen S, Gong Y, Guo M: EGFR and KRAS mutations in lung carcinoma: molecular testing by using cytology specimens. Cancer Cytopathol 2011;119: 111-117.

59 Folch E, Yamaguchi N, VanderLaan PA, Kocher ON, Boucher DH, Goldstein MA, Huberman MS, Kent MS, Gangadharan SP, Costa DB, Majid A: Adequacy of lymph node transbronchial needle aspirates using convex probe endobronchial ultrasound for multiple tumor genotyping techniques in non-smallcell lung cancer. J Thorac Oncol 2013;8:14381444.

60 Yarmus L, Akulian J, Gilbert C, Feller-Kopman D, Lee HJ, Zarogoulidis P, Lechtzin N, Ali SZ, Sathiyamoorthy V: Optimizing endobronchial ultrasound for molecular analysis. How many passes are needed? Ann Am Thorac Soc 2013;10:636-643.

61 Ulivi P, Puccetti M, Capelli L, Chiadini E, Bravaccini S, Calistri D, Zoli W, Amadori D, Candoli P: Molecular determinations of EGFR and EML4-ALK on a single slide of NSCLC tissue. J Clin Pathol 2013;66:708-710.

62 Bozzetti C, Naldi N, Nizzoli R, Azzoni C, Bortesi B, Zobbi V, Bottarelli L, Tiseo M, Gasparro D, Majori M, De Filippo M, Ardizzoni A: Reliability of EGFR and KRAS mutation analysis on fine-needle aspiration washing in non-small cell lung cancer. Lung Cancer 2013; $80: 35-38$.

63 da Cunha Santos G, Saieg MA, Geddie W, Leighl N: EGFR gene status in cytological samples of nonsmall cell lung carcinoma: controversies and opportunities. Cancer $\mathrm{Cy}$ topathol 2011;119:80-91.

-64 Horiike A, Kimura H, Nishio K, Ohyanagi F, Satoh Y, Okumura S, Ishikawa Y, Nakagawa K, Horai T, Nishio M: Detection of epidermal growth factor receptor mutation in transbronchial needle aspirates of non-small cell lung cancer. Chest 2007;131:1628-1634.
65 Nakajima T, Yasufuku K, Nakagawara A, Kimura $\mathrm{H}$, Yoshino I: Multigene mutation analysis of metastatic lymph nodes in nonsmall cell lung cancer diagnosed by endobronchial ultrasound-guided transbronchial needle aspiration. Chest 2011;140:1319-1324.

66 Garcia-Olive I, Monso E, Andreo F, Sanz-Santos J, Taron M, Molina-Vila MA, Llatjos M, Castella E, Moran T, Bertran-Alamillo J, Mayo-de-Las-Casas C, Queralt C, Rosell R: Endobronchial ultrasound-guided transbronchial needle aspiration for identifying EGFR mutations. Eur Respir J 2010;35:391-395.

67 van Eijk R, Licht J, Schrumpf M, Talebian Yazdi M, Ruano D, Forte GI, Nederlof PM, Veselic M, Rabe KF, Annema JT, Smit V, Morreau H, van Wezel T: Rapid KRAS, EGFR, BRAF and PIK3CA mutation analysis of fine needle aspirates from non-small-cell lung cancer using allele-specific qPCR. PLoS One 2011;6:e17791.

68 Jurado J, Saqi A, Maxfield R, Newmark A, Lavelle M, Bacchetta M, Gorenstein L, Dovidio F, Ginsburg ME, Sonett J, Bulman W: The efficacy of EBUS-guided transbronchial needle aspiration for molecular testing in lung adenocarcinoma. Ann Thorac Surg 2013;96: 1196-1202.

69 Savic S, Bode B, Diebold J, Tosoni I, Barascud A, Baschiera B, Grilli B, Herzog M, Obermann E, Bubendorf L: Detection of ALK-positive non-small-cell lung cancers on cytological specimens: high accuracy of immunocytochemistry with the $5 \mathrm{~A} 4$ clone. J Thorac Oncol 2013;8:1004-1011.

70 Sakairi Y, Nakajima T, Yasufuku K, Ikebe D, Kageyama H, Soda M, Takeuchi K, Itami M, Iizasa T, Yoshino I, Mano $\mathrm{H}$, Kimura $\mathrm{H}$ : EML4-ALK fusion gene assessment using metastatic lymph node samples obtained by endobronchial ultrasound-guided transbronchial needle aspiration. Clin Cancer Res 2010; 16:4938-4945.

71 Neat MJ, Foot NJ, Hicks A, Breen R, Wilkins B, McLean E, Santis G: ALK rearrangements in EBUS-derived transbronchial needle aspiration cytology in lung cancer. Cytopathology 2013;24:356-364.

72 Nakajima T, Zamel R, Anayama T, Kimura H, Yoshino I, Keshavjee S, Yasufuku K: Ribonucleic acid microarray analysis from lymph node samples obtained by endobronchial ultrasonography-guided transbronchial needle aspiration. Ann Thorac Surg 2012;94:20972101.

73 Mondoni M, Carlucci P, Di Marco F, Rossi S, Santus P, D'Adda A, Sferrazza Papa GF, Bulfamante G, Centanni S: Rapid on-site evaluation improves needle aspiration sensitivity in the diagnosis of central lung cancers: a randomized trial. Respiration 2013;86:52-58. 